See discussions, stats, and author profiles for this publication at: https://www.researchgate.net/publication/341946591

\title{
The anatomy of choice: an analysis of the determinants of local service delivery in Poland
}

Article in Local Government Studies · June 2020

DOI: $10.1080 / 03003930.2020 .1777108$

\section{CITATIONS}

3 authors:

António Tavares

University of Minho

69 PUBLICATIONS 1,029 CITATIONS

SEE PROFILE

Julita Lukomska

University of Warsaw

32 PUBLICATIONS 95 CITATIONS

SEE PROFILE
118

atarzyna Szmigiel-Rawska

Faculty of Geography and Regional Studies, University of Warsaw, Poland 45 PUBLICATIONS 138 CITATIONS

SEE PROFILE

Some of the authors of this publication are also working on these related projects:

Dualism in commune development in Poland in the context of policies and aspirations of local communities as well as external factors - compared to the chosen communities in EU View project

Financial cooperation of local governmnets View project 
Katarzyna Szmigiel-Rawska, Julita Łukomska \& António F. Tavares (2020) The anatomy of choice: an analysis of the determinants of local service delivery in Poland, Local Government Studies, DOI: 10.1080/03003930.2020.1777108

\title{
The Anatomy of Choice:
}

\section{An Analysis of the Determinants of Local Service Delivery in Poland}

\begin{abstract}
The aim of the paper is to identify the factors determining the choice between service delivery modes to provide local services. The original choice model proposed by Ferris and Graddy predicts that local officials seek to minimize service delivery costs (production and transaction costs), subject to political and fiscal constraints. The article tests production efficiency and transaction costs hypotheses in relation to the modes of service delivery adopted by local governments in Poland: in-house, corporatisation, cooperation, contracting out. It explores delivery choices of three different services: water supply, local transportation, and home care for elderly people. Based on the results of a nationwide survey addressed to all municipalities we test the aforementioned hypotheses using multinomial logit regression models. The empirical evidence confirms the basic expectations that the externalization of service delivery is a function of local officials' attempt to minimize the sum of production and transaction costs subject to fiscal and political constraints.
\end{abstract}

Key words: Delivery choices; Privatization; Intermunicipal Cooperation; Quantitative 


\section{Introduction}

During the past 30 years, a significant amount of research has been conducted to investigate the factors influencing the choice of governance mode to provide local services. Four modes have been distinguished and classified as predominant (Feiock et al. 2003; Carr et al. 2009; Rodrigues et al. 2012): in-house bureaucracy, municipal corporatisation, inter-municipal cooperation, and contracting out. While each of these four governance modes appears associated with multiple organizational forms, they tend to display significant intra-mode homogeneity.1

Local officials often act strategically and match services to alternative service delivery modes according to the limitations imposed by production efficiency concerns and the transaction costs involved in the exchange. Each local official faces a set of discrete choices to make, one for each service. Each choice involves the consideration of both production and transaction costs of producing a service and making it available to citizens (Ferris and Graddy 1986; 1991). Despite the extensive body of empirical research investigating the determinants of adoption of each one of the aforementioned delivery modes, few studies have explored the choice among several alternatives (see Carr et al. 2009; Feiock et al. 2003; Levin and Tadelis 2010; Rodrigues et al. 2012; Zullo 2009 for exceptions).

This research article contributes to this literature in a couple of ways. First, similar to a limited number of previous studies, we treat the choice among service delivery modes as a multiple choice rather than a dichotomous choice. However, unlike these earlier studies, we focus the research on the choice among delivery modes to provide services with different levels of asset

1 There are a few exceptions to this general statement. Mixed companies with a majority of private capital are a hybrid of corporatisation and contracting out, inter-municipal corporations are a hybrid of corporatisation and inter-municipal cooperation, and inter-municipal contracts with a private firm a hybrid of inter-municipal cooperation and contracting. 
specificity and service measurability features: water supply, local transportation, and home care for elderly people. Second, the research is located in an underexplored context, taking advantage of a large survey of municipalities in Poland. Prior research has been conducted overwhelmingly in North American and Western European settings, but far less attention has been devoted to Central and Eastern European (CEE) countries. This omission is particularly unfortunate, since Poland is a prime example of decentralization to sub-national levels among CEE countries and its local governments are more autonomous than their European counterparts are (Ladner et al., 2019).

Based on the results of a nationwide survey addressed to all Polish municipalities we test production efficiency and transaction costs hypotheses derived from the extant literature on service delivery using multinomial logit regression models. The empirical evidence indicates that local decision-makers choose externalization to minimize both production and transaction costs subject to fiscal and political constraints.

Following this introduction, the second section provides an overview of the transaction costs literature by focusing on the choice between modes to deliver public services. The third section introduces the theoretical framework and derives a set of key hypotheses linking production and transaction costs to the choice of delivery modes in the three types of services under analysis: water supply, public transport, and home care for the elderly. The fourth section describes the methods used to test these hypotheses and the data employed in the empirical analysis. Section five presents and discusses the findings of the multinomial logit regression models. The final section concludes and suggests directions for future research.

\section{Transaction Costs and Service Delivery Choices}

Over the past three decades, an extensive body of empirical work has been conducted in an attempt to uncover the factors influencing the adoption of different delivery modes of local 
goods and services. Contracting out is, perhaps, the most studied arrangement in this period (Ferris and Graddy, 1986, 1991, 1994; Morgan, Hirlinger and England, 1988; Clingermayer and Feiock, 1997; Wassenaar, Groot and Gradus, 2013; Zafra-Gómez et al., 2016; Bel and Fageda, 2017).

Starting at the end of the 1990s, researchers have focused attention on the establishment of corporate-like organizations at arms' length of local governments, better known as municipal corporations in Europe (Tavares and Camões, 2007, 2010) or public authorities in the U.S. (Bourdeaux, 2005). More recently, the determinants of multiple forms of inter-municipal cooperation have been investigated, including mixed firms (Bel and Fageda, 2010), interlocal agreements (LeRoux and Carr, 2007), and, more broadly, inter-municipal cooperation (Shrestha and Feiock, 2011; Bel, Fageda and Mur, 2013; Bel and Warner, 2016; Teles and Swianiewicz 2018; Łukomska and Szmigiel-Rawska, 2019). Here, we conceptualize cooperation more broadly as arrangements "that go beyond organisational borders in order to achieve specific results (...), including information sharing, interlocal contracts, and/or common policy actions" (Teles 2016: 10).

Despite the significant number of studies investigating the adoption of particular service delivery modes, only in a few instances have researchers tested empirical models seeking to explain the choice among more than one mode. Seminal work by Ferris and Graddy (1986) characterized the option as a production choice model with three major categories: in-house, public employees plus contracting and contracting out. The authors went on to state that once the contracting choice is made, local officials face a sector choice model, with contracting with a private firm seen as a default and contracting with other governments or non-profit providers seen as alternatives. Much of the work conducted in the next three decades follows the template set up by Ferris and Graddy, suggesting that both production and sector choices are driven largely by matching service characteristics and delivery modes for the services to be provided. 
In other words, local officials seek to minimize service delivery costs (production and transaction costs), subject to political and fiscal constraints (Ferris and Graddy, 1991).

Over the years, the assessment of transaction costs has faced several challenges with a corresponding diversification in the ways they are measured (Ferris and Graddy 1991; Nelson 1997). Brown and Potoski (2003) are credited with the attempt to measure transaction costs in a more direct way by assessing the levels of asset specificity and ease of measurement associated with each type of service. The authors asked ICMA survey respondents to rate each of the 64 services under analysis on a 1 to 5 scale for each of the transaction costs features. The study uses data from the 1997 ICMA survey and finds nonlinear relationships between service characteristics and externalization decisions. Compared to internal production, contracting with other governments, non-profit organizations and private firms initially declines with an increase in asset specificity, but increases for high levels of asset specificity. Regarding ease of measurement, contracting with private firms decreases from low to mid-levels of service measurability, but increases as services become more difficult to measure. In contrast, the relationship between service measurability and contracting with non-profits and other governments follows an inverted U-shape, i.e., lower at both the low and high levels of the service measurability spectrum.

Authors conducting empirical analyses in other contexts followed a similar procedure to Brown and Potoski's (2003). Lamothe, Lamothe and Feiock (2008) found that high asset specificity services were more likely to be contracted out to other governments and services which are difficult to measure were more likely to be contracted out to non-profit organizations and less likely to be contracted to for-profit firms. Extending Brown and Potoski's work, Carr et al. (2009) found that moderate asset specificity leads to higher probability of contracting with both other governments and nongovernmental providers, but this probability declines once asset specificity reaches extreme values in the upper end of the spectrum. Contracting with other 
governments increases with moderate levels of service measurability and declines at higher values. This relationship is reversed when contracting with nongovernmental providers. Levin and Tadelis (2010) concluded that services involving higher transaction costs were less likely to be contracted out. Similarly, services cities define as "core services" were also less likely to be externalized because cities wish to retain control over their provision. Hefetz and Warner (2012) found that contract management difficulty appears associated with an increase in intergovernmental contracts. Consistent with the findings by Carr et al. (2009), recent work by Hultquist et al. (2017) concludes that moderate levels of asset specificity are associated with higher probability of contracting with other governments and joint contracting. The relationship follows, therefore, an inverted-U shape. In contrast, contract with a private or non-profit partner is driven by service measurability concerns: contracting decreases as service measurability increases from low to moderate levels, but increases again at very high levels of service measurability.

This section presented a brief literature review of past empirical studies investigating the association between service characteristics and the choice of governance modes for service delivery. While not entirely consistent across geographical contexts and over time, the studies allow the extraction of hypotheses to be tested using service delivery data from local governments in Poland. The following section elaborates on the expected theoretical mechanisms and derives a set of hypotheses based on the original Ferris and Graddy (1986; 1991) model and framed by the evolution of the empirical literature published in the past three decades.

\section{Theoretical Framework and Hypotheses}

The original model by Ferris and Graddy (1991) predicts that local officials seek to minimize service delivery costs (production and transaction costs), subject to political and fiscal 
constraints. This article performs a test of the theoretical model developed by Ferris and Graddy applied to the Polish local government context. The following sub-sections state the hypotheses derived from their model and ground them in the extant literature.

\section{Production costs and efficiency hypotheses}

Cost savings and the search for more efficient modes of organization often motivate the externalization of service delivery. This search for efficiency in service delivery is typically associated with the size and scale of production activities. The contracting out literature shows that capital-intensive services are more likely to display scale economies than labour-intensive services (Petersen et al. 2018). Controlling for service type, larger municipalities should be better able to capture scale economies through market-based solutions.

The general argument is that both competition and private sector ownership stimulate efficiency. Competition increases pressures to innovate, benchmarking, and cost minimization, whereas private ownership encourages accountability to shareholders and owners (Petersen, Hjelmar and Vrangbæk 2018). In addition, single-purpose organizations such as municipal corporations are less subject to the constraints imposed by administrative law and better able to take advantage of size, density, specialization, and more flexible management rules (Tavares and Camões 2010). Hence, larger municipalities may prefer to rely on contracting with private firms or establishing a municipal corporation to take advantage of potential economies of scale (Hefetz et al. 2012). In contrast, Bel and Sebö (2019) correctly point out that inter-municipal cooperation is a way of accomplishing scale economies while keeping service provision under public delivery. Thus, smaller municipalities may benefit more from inter-municipal agreements than larger municipalities (Levin and Tadelis, 2010; Bel, Fageda and Mur, 2014). This leads to the following predictions: 
Hla: More populated municipalities are more likely to contract with a private firm or rely on a municipal corporation for service delivery.

H1b: Less populated municipalities are more likely to engage in inter-municipal cooperation than larger municipalities.

Economies of density are another potential source of efficiency in service delivery (Ladd 1992). The spatial proximity of service users is likely to translate into cost savings for providers, particularly for services based on network infrastructure such as water supply or public transportation (Rodrigues and Tavares 2017). All else equal, more densely populated municipalities are in a better position to attract private firm investments and inter-municipal agreements as well as capture cost savings through corporatization. In addition, higher densities occur in urban areas, where firms are also likely to take advantage of economies of agglomeration related to the concentration of economic activity (Petersen, Hjelmar and Vrangbæk 2018). Hence, it is expected that all forms of externalization will be better able to capture economies of density and agglomeration:

H2: More densely populated municipalities are more likely to adopt externalized forms of service delivery.

Externalized forms of service delivery such as the ones investigated in this research tend to be more specialized than general-purpose governments operating with their in-house bureaucracies (Tavares and Camões 2007; Rodrigues et al. 2012). Increased specialization in service delivery allows single-purpose organizations to adjust to changes in citizen preferences, which are more likely to occur in municipalities experiencing fast-paced growth. Hence, it is expected that: 
H3: Municipalities experiencing fast growth are more likely to choose externalized forms of service delivery.

Externalization is also likely to result in lower labour costs. Public sector laws tend to be much more rigid than private sector laws, including commercial law, financial laws, and procurement and human resources practices (Tavares and Camões 2007). Avoiding civil service, financial, and public procurement laws allows external providers to perform more efficiently, so externalization becomes an attractive solution when municipalities are negatively affected by higher labour costs, particularly those associated with labour-intensive services such as homecare for the elderly (Petersen et al. 2018).

H4: Municipalities facing higher labour costs are more likely to externalize their services.

\section{Transaction costs hypotheses}

In principle, externalization is able to deliver cost savings in production, but this is often accompanied by increased transaction costs in the externalization process (Williamson, 1979; Brown and Potoski, 2003a). However, contrary to production cost savings ensuing from externalization, transaction costs can vary significantly depending on the choice of service delivery arrangement. Under municipal corporation arrangements, transaction costs can still be kept low, not only because the municipality controls the majority of shares in the company, but also because the local corporate public sector is often subject to a mix of public and private laws (Tavares and Camões 2007, 2010). Transaction costs are expected to be higher in the case of inter-municipal arrangements due to the multiple principal problem identified by Voorn and colleagues (Voorn, van Genugten and van Thiel 2019). Contracting out with the private sector 
is also subject to high transaction costs due to the difficulty in designing, monitoring, and enforcing contracts to prevent opportunism of profit-seeking firms (Williamson 1979).

Given the risk of opportunism associated with contracting out with the private sector, we expect that the probability of contracting will decline as the level of asset specificity increases (Lamothe et al. 2008; Levin and Tadelis 2010). Consistent with prior works, we predict that the relationship between asset specificity and both corporatization and contracting with other governments will follow an inverted U-shape. In other words, moderate levels of asset specificity increase the likelihood of contracting out using these modes of organization of service delivery (Carr et al. 2009; Shrestha and Feiock 2011; Hultquist et al. 2017). Two complementary hypotheses concerning asset specificity are tested:

H5a: Services involving highly specific assets are less likely to be externalized to a private firm.

H5b: When externalization is considered an alternative to in-house production, local officials are more likely to create a municipal corporation or cooperate with other governments to produce highly specific assets.

Another source of transaction costs is the degree of service measurability. Service that are easier to measure are more likely to be contracted out due to fewer concerns with opportunistic behaviour by the private partner (Lamothe et al. 2008; Rodrigues et al. 2012). Services involving higher contracting difficulty are more challenging to monitor and thus less likely to be contracted out to nongovernmental providers (Levin and Tadelis 2010; Hefetz and Warner 2012). Bel and Warner's (2016) meta-regression indicates that service level transaction costs have either positive or non-significant effects on the levels of cooperation. Hence, we expect that:

H6a: Services that are easier to measure are more likely to be externalized. 
H6b: When externalization is considered as an alternative to in-house production, local officials are more likely to create a municipal corporation or cooperate with other governments to produce complex or difficult to measure services.

\section{Fiscal and Political Constraints}

Following the Ferris and Graddy (1991) model, we also take into account fiscal constraints and political transaction costs. Municipalities facing fiscal stress are more likely to externalize services as an attempt to overcome lower fiscal capacity (Joassart-Marcelli and Musso 2005) and higher debt (Zullo 2009). The motivation to externalize under situations of fiscal stress may also relate to the need to avoid service disruptions or shift blame to other providers. Consistent with this idea, political instability is also expected to increase the probability of externalizing service provision (Rodrigues et al. 2012).

\section{Institutional Framework of Local Service Delivery in Poland}

The municipal level is the most active when it comes to public service provision among the three subnational levels of government in Poland. General spending of non-central governments in Poland represents about $40 \%$ of public spending and municipal spending is 33\% (Ministry of Finance, 2018). Municipalities provide a broad range of services, including primary education, water and sewage management, waste collection, public transport, and social care. Our analysis focuses on three of these services: water supply, public transport, and social care for the elderly.

Water supply and wastewater management consumed a large portion of municipal investments in the last decade and stand as one of the most commonly provided services, together with primary education and social care. According to the legal definition in Poland, local public 
transport is publicly available, regular passenger transport carried out at specified intervals and along specific communication lines. The public transport operator performs this service in order to meet the transportation needs of communities in a given area on an ongoing and continuous basis. Day care services for the elderly include assistance in meeting daily life needs, hygiene care, and physician-recommended care. Where possible, day care workers provide social contact for those who are unable to function independently and who need support in their daily tasks. Some of these services are specialized due to the resident's illness or disability.

These services differ due to how many municipalities provide each of them according to the estimations based on our questionnaire. Eighty-four percent of all the municipalities supply drinking water, collect wastewater, and manage its presence in the environment. Day care services are provided by $67 \%$ and local public transport by $36 \%$ of all municipalities surveyed.

\section{Data and Methods}

During the year of 2018, we conducted a nationwide survey of all 2,478 municipalities in Poland. A sample of 1,080 valid responses was obtained and it will be employed in the analyses detailed below. Compared to all 2478 municipalities in Poland, the municipalities in our sample are more populous (sample mean=23631; population mean=15510), denser $($ sample=299; population=220) and slightly wealthier (sample=653; population=602). Municipal debt per capita and EU grants per capita are about the same for both the sample and the population of municipalities. Overall, the differences between sample and population are fairly minor and should not prevent us from generalizing the results for all municipalities in Poland.

The dependent variable is the governance mode adopted by three services in the 1,080 municipalities in the past two years: water supply, local transportation, and home care for elderly people. Pooling the data for these services, the maximum number of observations included in the analysis could be $3,240(=1,080 * 3)$. However, because not all municipalities 
provide the three services under analysis, the final number of observations equals 1,809 . These observations constitute the dependent variable and take on one of four possible nominal outcomes: in-house $(=858)$, municipal corporatization $(=286)$, inter-municipal cooperation (=377) and private contracting (=288). These four governance modes result from the collapse of the 15 organizational forms identified in Table 1. This classification of organizational forms into governance modes follows similar examples extracted from the literature (Rodrigues et al. 2012). In line with the broad definition of cooperation outlined above, this governance mode encompasses interlocal contracts and agreements with other local governments as well as with non-profit organizations.

\section{[Table 1 about here]}

The empirical models are designed to include four types of theoretical variables aligned with the framework developed in section three. First, production efficiency is assessed by four indicators: 1) municipal population size, to consider scale economies in municipal choices; 2) population density, to account for possible economies of density; 3) population change, to account for variations in preference diversity and control for possible pressures over service capacity; and 4) labour costs measured as expenditures on local administration per capita to account for costs with human resources.

Second, transaction costs are measured using the predominant indicators in the literature. We assess the varying levels of asset specificity and ease of measurement of the three services by asking officials to rate each municipal service on ordinal scales ranging from 1 (low) to 5 (high) (Brown and Potoski 2003; Rodrigues et al. 2012). Because asset specificity and ease of measurement and monitoring might not be the only service characteristics to consider, we also included dichotomous variables for two of the three services under analysis (water and transportation) to control for other omitted features. 
Third, fiscal capacity and constraints are accounted for by four indicators: 1) income, measured as the local budget revenues from tax sharing (per capita); 2) financial autonomy, assessed by the share of own revenues derived from local taxes and fees in the total budget; 3) short-term financial conditions, measured by the operational surplus of the local budget (difference between current revenues and current expenditures), per capita; and 4) long-term financial conditions, assessed by the total amount of debt per capita incurred by the municipality.

Fourth, political constraints are controlled for by including a political stability measure of the count of terms served by the mayor.

Lastly, we include several control variables: 1) a dummy variable for municipalities located in the former Russian and Austrian occupation areas; 2) European Union expenditures as the value of municipal budget expenditures financed by EU grants (per capita); and 3) a network embeddedness variable as the number of inter-municipal organizations of which the municipality is a member (per capita). Table 2 displays the variables, indicators, variable sources, and descriptive statistics for the variables employed in the empirical analyses conducted in the next section.

[Table 2 about here]

The empirical analyses employ multinomial logit regression models, which are the most appropriate for estimating unordered, multi-category dependent variables. This is the appropriate regression tool when the dependent variable is a nominal one (Liao 1994; Borooah 2002). The model assumes a reference category (in our case, in-house production), and provides the odds, in probabilistic terms, of the other categories (municipal corporatisation, cooperation, and contracting out) (Borooah 2002, Liao 1994). This econometric model employs maximum likelihood for estimating regression coefficients. The method is used in logit models because 
the errors do not follow a normal distribution and do not have constant variance. Robust standard errors are calculated with the Huber/White/Sandwich (HWS) variance estimator.

\section{Findings and Discussion}

Table 3 presents the results of the multinomial logit regression models. The table contains eight different specifications, which serve both as tests of the different hypotheses and as robustness checks of the results. The eight specifications are also justified to avoid excessive collinearity between independent variables (e.g. population and population density). The first specification is the base model without controls. It includes all the theoretical variables related to production efficiency and transaction costs, with the exception of density. The results show some support for H1a as larger municipalities are more likely to externalize services by contracting out with the private sector. This finding is robust to the inclusion of all control variables (specification (2)). The population variable is also statistically significant for corporatisation, but fails to reach significance once the controls are added. Contrary to the prediction of $\mathrm{H} 1 \mathrm{~b}$, population size is also positively associated with inter-municipal cooperation. This contradicts prior studies suggesting that smaller municipalities are more inclined to cooperate (Levin and Tadelis 2010; Bel et al. 2014), supporting instead the idea of more mixed findings emerging from Bel and Warner's (2016) meta-regression. Lastly, we also test the nonlinear relationship between population size and service delivery choices, but none of the coefficients lend support to the economies of scale argument.

The third specification is the same as (2) but includes density as a predictor. Population density is a more robust predictor than population. Municipalities with higher density tend to externalize services using one of the three possible modes of delivery. The results are stronger for municipal corporatization, but they are equally positive and significant for the cooperation and contracting with a private firm modes. In line with prior work in the water sector (Rodrigues 
and Tavares 2017), these results indicate the presence of economies of density for the three services under analysis here and provide strong support for $\mathrm{H} 2$.

In contrast, the population growth variable exhibits less consistent findings. Fast growing municipalities are less likely to externalize to municipal corporations. Beyond this finding, no other consistent result emerges from the analysis. Hence, we fail to find support for the third hypothesis regarding the role of preference diversity as a stimulus to externalization. Lack of consistency is also the dominant trait in testing $\mathrm{H} 4$. The results suggest that higher labour costs lead to less externalization, both through corporatisation and contracting with the private sector. This finding is quite puzzling, as we would expect the minimization of production costs to be the main driver to externalization. One possible explanation for this unexpected result might be the fact that we are not able to measure labour costs for each individual service, since the variable only captures overall spending by the local administration, not costs with specific services.

As expected, transaction costs emerge as relevant predictors of the choice of service delivery modes. We find strong support for the idea that services involving high asset specificity tend to be less contracted out to the private sector, which confirms H5a and prior work by Lamothe et al. (2008) and Levin and Tadelis (2010). Regarding H5b, specification (4) tests and confirms the existence of a nonlinear relationship between asset specificity and the use of corporatisation, but not cooperation. Municipal corporations tend to be adopted under moderate asset specificity, but local governments avoid this mode of delivery under conditions of both high and low asset specificity. This finding supports $\mathrm{H} 5 \mathrm{~b}$ and is partially consistent with prior work by Carr et al. (2009) and Hulquist et al. (2017).

Ease of monitoring is relevant for the choice of service delivery mode. Services that are easier to monitor are more likely to be targeted for cooperation or contracted to the private sector. 
This result supports H6a and several empirical analysis present in the literature (Lamothe et al. 2008; Hefetz et al. 2012). In contrast, we do not find support for H6b: ease of monitoring is unrelated with corporatization and it is positively associated with cooperation. Ease of measurement and monitoring is important under inter-municipal cooperation arrangements due to the multiple principal problem identified by Voorn et al. (2019). Again, just as with asset specificity, services that are more difficult to monitor tend to be provided in-house.

The seventh specification includes interaction terms between population and service type to account for the possibility that water and transportation are better able to capture scale economies than homecare services. Interestingly, while the provision of water is negatively associated with externalization modes, the interaction term between water and population is positive for all modes. This suggests that the externalization of water supply is the preferred mode for larger municipalities, which is also consistent with the economies of scale argument posited in H1 and prior findings obtained by Rodrigues and Tavares (2017) for the water sector in Portugal. Similarly, specification (8) includes an interaction term between labour costs and homecare to test the possibility that the multiplicative effect of these variables is a deterrent to externalization. The findings fail to support this idea for all externalization modes.

The variables controlling for fiscal constraints and political transaction costs also display interesting results. Income is positive and significant for all types of externalization, indicating that wealthier communities are more likely to prefer externalization to in-house service delivery. This finding is in line with prior work in the Danish context suggesting that externalization is associated with 'good times' (Pallesen 2004). The remaining variables assessing the role of fiscal constraints are only statistically significant and positive in the case of corporatization. Budget surplus and debt are associated with externalization to municipal corporations. Political stability does not appear to be associated with either corporatization or cooperation, but it is a positive and statistically significant predictor of contracting out with the 
private sector, thus contrasting with findings in other contexts (Rodrigues et al. 2012). In other words, political stability measured as the number of consecutive terms served by the mayor reduces the political transaction costs associated with contracting out to the private sector.

As expected, services provided in municipalities belonging to a large number of inter-municipal organisations are more likely to use cooperation and private sector delivery. They are also less likely to rely on municipal corporations. This combination of results is consistent with the view that lower network embeddedness leads municipalities to 'go at it alone'. Municipalities located in formerly Russian and Austrian territories are less likely to externalize services to the three modes of delivery.

\section{Conclusions and Directions for Future Research}

This article represents the first attempt to analyse service delivery choices by local governments in Poland. Based on the Ferris and Graddy (1991) classical model, we argue that service delivery choices are driven primarily by an attempt of local officials to minimize the sum of production and transaction costs subject to fiscal and political constraints. The empirical analysis was devised to test a set of hypotheses derived from this model in the context of the Polish local government system. Due to limitations in data collection, the analysis is limited to three services: water supply, public transportation, and home care for the elderly.

The findings largely support the main tenets of the Ferris and Graddy model. First, the minimization of production costs is a key concern among local officials. Larger municipalities are more likely to deliver services through cooperation with other governments and contracting with private firms, thus suggesting the active search for scale economies using these forms of service delivery. The findings also support the presence of economies of density, as municipalities with higher population density associated with the use of all three forms of externalization. 
The transaction costs associated with service characteristics are also an important determinant. Higher asset specificity reduces the likelihood of externalization for all three modes, but we do find indication of a nonlinear relationship with corporatization. Ease of measurement and monitoring is associated with higher likelihood of externalization to inter-municipal cooperation forms and private contracting. Contrary to asset specificity, we do not find evidence of nonlinearities in the case of service monitoring.

Two important policy implications result from the findings. First, political stability is important when contracting out to private agents. In 2018, new legislation approved term limits to mayors (two 5-year terms). The replacement of mayors serving for many years may cause disruptions in service delivery, particularly in those services provided by private agents under contract. This will require careful monitoring and some capacity building for newly elected mayors. Second, density is not a factor taken into consideration in the public discourse on territorial reforms or local public finance. The size of municipality, while relevant, does not seem to have a consistent impact on choices across the board. In Poland, density is a much better predictor of service delivery mode and should be recognized by local officials and decision-makers as an important driver of service delivery choices.

This study suffers from a few of important limitations. First, the majority of prior research was conducted in the United States and the United Kingdom, with more recent work also extending to several other Western European countries. While studying service delivery choices by local governments in Poland is certainly a relevant contribution to expand empirical testing to other countries "with different regulatory, ideological and institutional contexts" (Petersen et al. 2018: 132), it is nevertheless insufficient for generalizing the results to other CEE countries. Poland's local governments hold a unique status in terms of decentralization and autonomy when compared to their counterparts in other CEE countries, which makes the generalization of the findings difficult to defend. The second major limitation is the number of services 
covered in the analysis. Collecting data on close to 50 services provided by local governments in Poland is a large-scale endeavour and not viable without a major project. Instead, we opted to collect data on three services providing significant contrasts in terms of production and transaction costs. While not ideal, this approach carries some level of confidence regarding the findings. The third major limitation is the absence of a longitudinal analysis of choices. The research described in this article offers a static picture of local governments' service delivery choices at a point in time. Ideally, longitudinal data would allow a more comprehensive view of choices over time.

The plethora of studies of service delivery choices in the Anglo-Saxon and Western European contexts contrasts with research on this topic in CEE countries, where empirical analyses are still in their infancy. Future research should strive to conduct more case studies along similar lines to the one followed here, as well as engage in comparative case studies to test the generalizability of the Ferris and Graddy $(1986,1991)$ model. Additionally, we expect to conduct case study research in Poland to complement the findings obtained from this large $\mathrm{N}$ analysis. 
Table 1 - Organizational Forms and Governance Modes

\begin{tabular}{|c|c|}
\hline Organizational Form & Governance Mode \\
\hline $\begin{array}{l}\text { Municipal government and/or budgetary unit } \\
\text { Budgetary establishment }\end{array}$ & In-house \\
\hline $\begin{array}{l}\text { Municipal company (100\% municipality } \\
\text { ownership) } \\
\text { Mixed company (50-100\% municipality } \\
\text { ownership) }\end{array}$ & Corporatization \\
\hline $\begin{array}{l}\text { Mixed company (less than } 50 \% \text { municipality } \\
\text { ownership) } \\
\text { Contract with private enterprise } \\
\text { Inter-municipal contract with private enterprise }\end{array}$ & Private contracting \\
\hline $\begin{array}{l}\text { Purchase from other local government (with or } \\
\text { without a contract) } \\
\text { Contract with a non-governmental organisation } \\
\text { (e.g. association, foundation, etc.) } \\
\text { Purchase from external organisation established } \\
\text { by other local government } \\
\text { Inter-municipal company } \\
\text { Inter-municipal joint authority } \\
\text { Metropolitan joint authority } \\
\text { Administrative agreement } \\
\text { Inter-municipal contract with non-governmental } \\
\text { organisation (e.g. association, foundation, etc.) }\end{array}$ & Inter-municipal cooperation \\
\hline
\end{tabular}


Table 2 - Descriptive Statistics

\begin{tabular}{|c|c|c|c|c|c|c|c|}
\hline $\begin{array}{l}\text { Independent } \\
\text { variables }\end{array}$ & Indicators & $\begin{array}{l}\text { Year of data } \\
\text { collection }\end{array}$ & Sources & Mean & SD & Min & Max \\
\hline Population & Size of municipal population & 2017 & Main Statistical Office & 23631 & 67757 & 1644 & 767348 \\
\hline $\begin{array}{l}\text { Change in } \\
\text { population }\end{array}$ & $\begin{array}{l}\text { Population change measured using the formula: } \\
\text { (population2017 - } \\
\text { population2012)*100/population } 2012\end{array}$ & 2012,2017 & Main Statistical Office & -0.17 & 4.62 & -34.82 & 27.51 \\
\hline Population density & Population per square $\mathrm{km}$ & 2017 & Main Statistical Office & 298.81 & 559.03 & 4.37 & 3991.21 \\
\hline Labour costs & Local administration expenditures per capita & 2017 & $\begin{array}{l}\text { Ministry of Finance, reports } \\
\text { on local budget execution }\end{array}$ & 423.38 & 139.50 & 179.09 & 1999.50 \\
\hline Asset specificity & $\begin{array}{c}\text { Mean of asset specificity measured by the sum } \\
\text { of answers to the survey (coded } 1 \text { to } 5 \text { ) divided } \\
\text { by the number of survey responses }\end{array}$ & 2018 & Survey & 3.48 & 0.70 & 1.00 & 5.00 \\
\hline Ease of Monitoring & $\begin{array}{l}\text { Mean of all monitoring items measured by the } \\
\text { sum of responses to the survey (coded } 1 \text { to } 5 \text { ) } \\
\text { divided by the number of survey responses }\end{array}$ & 2018 & Survey & 2.39 & 1.05 & 1.00 & 5.00 \\
\hline Income & $\begin{array}{l}\text { Local budget revenues from tax sharing } \\
\text { (Personal Income Tax) per capita }\end{array}$ & 2017 & $\begin{array}{l}\text { Ministry of Finance, reports } \\
\text { on local budget execution }\end{array}$ & 653.13 & 346.11 & 178.26 & 3383.68 \\
\hline
\end{tabular}




\begin{tabular}{|c|c|c|c|c|c|c|c|}
\hline $\begin{array}{l}\text { Municipality own } \\
\text { revenue (financial } \\
\text { dependency) }\end{array}$ & $\begin{array}{c}\text { Share of own revenues (mainly from local taxes, } \\
\text { fees and tax sharing) in total revenues of local } \\
\text { budget }\end{array}$ & 2017 & $\begin{array}{l}\text { Ministry of Finance, reports } \\
\text { on local budget execution }\end{array}$ & 38.67 & 13.84 & 10.74 & 92.41 \\
\hline Budget surplus & $\begin{array}{c}\text { Operational surplus of local budget (difference } \\
\text { between current revenues and current } \\
\text { expenditures) per capita }\end{array}$ & 2017 & $\begin{array}{l}\text { Ministry of Finance, reports } \\
\text { on local budget execution }\end{array}$ & 480.98 & 631.56 & -1448.29 & 14944.75 \\
\hline Debt & Debt per capita (in PLN) & 2017 & $\begin{array}{l}\text { Ministry of Finance, reports } \\
\text { on local budget execution } \\
\text { (2012-2017) }\end{array}$ & 987.78 & 730.83 & 0.00 & 4929.69 \\
\hline EU Expenditures & $\begin{array}{l}\text { Municipal budget expenditures financed from } \\
\text { EU grants per capita (in PLN) }\end{array}$ & $\begin{array}{l}2012,2013 \\
2014,2015 \\
2016,2017\end{array}$ & $\begin{array}{l}\text { Ministry of Finance, reports } \\
\text { on local budget execution } \\
\text { (2012-2017) }\end{array}$ & 908.01 & 687.64 & 11.29 & 6938.64 \\
\hline $\begin{array}{l}\text { Network } \\
\text { Embeddedness }\end{array}$ & $\begin{array}{l}\text { Number of inter-municipal organisations of } \\
\text { which the municipality is a member, per } 10000 \\
\text { inhabitants }\end{array}$ & 2015 & (Kołsut, 2015) & 2.79 & 2.52 & 0.00 & 17.07 \\
\hline Political stability & $\begin{array}{l}\text { Each second and following mayor's term } \\
\text { counted from local elections in } 2002\end{array}$ & $\begin{array}{l}2002,2006 \\
2010,2014\end{array}$ & $\begin{array}{l}\text { Central Electoral } \\
\text { Commission }\end{array}$ & 1.98 & 0.84 & 0.00 & 3.00 \\
\hline Location & $\begin{array}{c}\text { Dichotomous variable for municipalities located } \\
\text { in the region that was a part of Russian or } \\
\text { Austrian states in 1795-1918 }\end{array}$ & 2018 & Main Statistical Office & & & 0 & 1 \\
\hline
\end{tabular}


Table 3. Multinomial logit regression estimations - Corporatization

\begin{tabular}{|c|c|c|c|c|c|c|c|c|}
\hline & (1) & (2) & (3) & (4) & (5) & (6) & (7) & $(8)$ \\
\hline Population & $\begin{array}{c}0.000^{* * *} \\
(0.000)\end{array}$ & $\begin{array}{c}0.000 \\
(0.000)\end{array}$ & $\begin{array}{c}0.000 \\
(0.000)\end{array}$ & $\begin{array}{c}0.000 \\
(0.000)\end{array}$ & $\begin{array}{c}0.000 \\
(0.000)\end{array}$ & $\begin{array}{c}0.000 \\
(0.000)\end{array}$ & $\begin{array}{c}0.000 * * * \\
(0.000)\end{array}$ & $\begin{array}{c}0.000 \\
(0.000)\end{array}$ \\
\hline Population sq. & & & & & & $\begin{array}{c}0.000 \\
(0.000)\end{array}$ & & \\
\hline Population*Water & & & & & & & $\begin{array}{c}0.000 * * * \\
(0.000)\end{array}$ & \\
\hline Population*Transportation & & & & & & & $\begin{array}{l}0.000 \\
(0.000)\end{array}$ & \\
\hline Labor Costs & $\begin{array}{c}-0.002^{* * *} \\
(0.001)\end{array}$ & $\begin{array}{c}-0.006^{* * *} \\
(0.001)\end{array}$ & $\begin{array}{c}-0.005^{* * *} \\
(0.001)\end{array}$ & $\begin{array}{c}-0.006^{* * *} \\
(0.001)\end{array}$ & $\begin{array}{c}-0.006^{* * *} \\
(0.001)\end{array}$ & $\begin{array}{c}-0.006^{* * *} \\
(0.001)\end{array}$ & $\begin{array}{c}-0.005^{* * *} \\
(0.001)\end{array}$ & $\begin{array}{c}-0.006^{* * *} \\
(0.001)\end{array}$ \\
\hline Labor Costs*Homecare & & & & & & & & $\begin{array}{c}0.001 \\
(1.572)\end{array}$ \\
\hline Density & & & $\begin{array}{c}0.001^{* * *} \\
(0.000)\end{array}$ & & & & & \\
\hline Population Growth & $\begin{array}{c}0.012 \\
(0.016)\end{array}$ & $\begin{array}{c}-0.064^{* * *} \\
(0.023)\end{array}$ & $\begin{array}{c}-0.042^{*} \\
(0.024)\end{array}$ & $\begin{array}{c}-0.066^{* * *} \\
(0.024)\end{array}$ & $\begin{array}{c}-0.064^{* * * *} \\
(0.023)\end{array}$ & $\begin{array}{c}-0.064^{* * * *} \\
(0.024)\end{array}$ & $\begin{array}{c}-0.067^{* * *} \\
(0.024)\end{array}$ & $\begin{array}{c}-0.064^{* * *} \\
(0.023)\end{array}$ \\
\hline Asset Specificity & $\begin{array}{c}-0.529^{* * *} \\
(0.105)\end{array}$ & $\begin{array}{c}-0.655^{* * * *} \\
(0.130)\end{array}$ & $\begin{array}{c}-0.662^{* * *} \\
(0.130)\end{array}$ & $\begin{array}{c}1.805^{* *} \\
(0.894) \\
\end{array}$ & $\begin{array}{c}-0.649^{* * *} \\
(0.130)\end{array}$ & $\begin{array}{c}-0.652^{* * *} \\
(0.130)\end{array}$ & $\begin{array}{c}-0.623^{* * *} \\
(0.131)\end{array}$ & $\begin{array}{c}-0.655^{* * *} \\
(0.130)\end{array}$ \\
\hline Asset Specificity sq. & & & & $\begin{array}{c}-0.363^{* * * *} \\
(0.131)\end{array}$ & & & & \\
\hline Ease of Monitoring & $\begin{array}{l}-0.036 \\
(0.081) \\
\end{array}$ & $\begin{array}{l}-0.152 \\
(0.101)\end{array}$ & $\begin{array}{l}-0.145 \\
(0.102) \\
\end{array}$ & $\begin{array}{l}-0.173^{*} \\
(0.102)\end{array}$ & $\begin{array}{c}0.305 \\
(0.461)\end{array}$ & $\begin{array}{l}-0.156 \\
(0.101)\end{array}$ & $\begin{array}{l}-0.143 \\
(0.103) \\
\end{array}$ & $\begin{array}{l}-0.153 \\
(0.101)\end{array}$ \\
\hline Ease of Monitoring sq. & & & & & $\begin{array}{c}-0.094 \\
(0.093)\end{array}$ & & & \\
\hline Income & & $\begin{array}{c}0.002^{* * * *} \\
(0.001)\end{array}$ & $\begin{array}{c}0.001^{* *} \\
(0.001)\end{array}$ & $\begin{array}{c}0.002^{* * * *} \\
(0.001)\end{array}$ & $\begin{array}{c}0.002^{* * *} \\
(0.001)\end{array}$ & $\begin{array}{c}0.002^{* * *} \\
(0.001)\end{array}$ & $\begin{array}{c}0.002^{* * *} \\
(0.001)\end{array}$ & $\begin{array}{c}0.002^{* * *} \\
(0.001)\end{array}$ \\
\hline Financial autonomy & & $\begin{array}{c}0.013 \\
(0.013)\end{array}$ & $\begin{array}{c}0.008 \\
(0.013)\end{array}$ & $\begin{array}{c}0.008 \\
(0.013)\end{array}$ & $\begin{array}{c}0.013 \\
(0.013)\end{array}$ & $\begin{array}{c}0.013 \\
(0.013) \\
\end{array}$ & $\begin{array}{c}0.004 \\
(0.013) \\
\end{array}$ & $\begin{array}{c}0.013 \\
(0.013) \\
\end{array}$ \\
\hline Budget surplus & & $\begin{array}{c}0.001^{* * *} \\
(0.000)\end{array}$ & $\begin{array}{c}0.001^{* * * *} \\
(0.000)\end{array}$ & $\begin{array}{c}0.001^{* * * *} \\
(0.000)\end{array}$ & $\begin{array}{c}0.001^{* * *} \\
(0.000)\end{array}$ & $\begin{array}{c}0.001^{* * * *} \\
(0.000)\end{array}$ & $\begin{array}{c}0.001^{* * *} \\
(0.000)\end{array}$ & $\begin{array}{c}0.001^{* * *} \\
(0.000)\end{array}$ \\
\hline Debt & & $\begin{array}{c}0.001^{* * * *} \\
(0.000)\end{array}$ & $\begin{array}{c}0.001^{* * * *} \\
(0.000)\end{array}$ & $\begin{array}{c}0.001^{* * * *} \\
(0.000)\end{array}$ & $\begin{array}{c}0.001^{* * * *} \\
(0.000)\end{array}$ & $\begin{array}{c}0.001^{* * *} \\
(0.000)\end{array}$ & $\begin{array}{c}0.001^{* * *} \\
(0.000)\end{array}$ & $\begin{array}{c}0.001^{* * *} \\
(0.000)\end{array}$ \\
\hline EU Expenditures & & $\begin{array}{l}0.000^{*} \\
(0.000)\end{array}$ & $\begin{array}{l}0.000^{*} \\
(0.000)\end{array}$ & $\begin{array}{l}0.000^{*} \\
(0.000)\end{array}$ & $\begin{array}{l}0.000^{*} \\
(0.000)\end{array}$ & $\begin{array}{l}0.000^{*} \\
(0.000)\end{array}$ & $\begin{array}{c}0.000 \\
(0.000)\end{array}$ & $\begin{array}{l}0.000^{*} \\
(0.000)\end{array}$ \\
\hline Political stability & & $\begin{array}{l}-0.092 \\
(0.118)\end{array}$ & $\begin{array}{l}-0.093 \\
(0.118)\end{array}$ & $\begin{array}{l}-0.095 \\
(0.119)\end{array}$ & $\begin{array}{l}-0.082 \\
(0.119)\end{array}$ & $\begin{array}{l}-0.097 \\
(0.120)\end{array}$ & $\begin{array}{l}-0.078 \\
(0.120)\end{array}$ & $\begin{array}{l}-0.092 \\
(0.118)\end{array}$ \\
\hline Network embeddedness & & $\begin{array}{c}-0.210^{* * *} \\
(0.059)\end{array}$ & $\begin{array}{c}-0.200^{* * *} \\
(0.059)\end{array}$ & $\begin{array}{c}-0.212^{* * *} \\
(0.059)\end{array}$ & $\begin{array}{c}-0.211^{* * *} \\
(0.059)\end{array}$ & $\begin{array}{c}-0.213^{* * *} \\
(0.060)\end{array}$ & $\begin{array}{c}-0.175^{* * *} \\
(0.059)\end{array}$ & $\begin{array}{c}-0.210^{* * *} \\
(0.059)\end{array}$ \\
\hline Location & & $\begin{array}{c}1.064^{* * *} \\
(0.196)\end{array}$ & $\begin{array}{c}1.059^{* * *} \\
(0.197)\end{array}$ & $\begin{array}{c}1.053^{* * *} \\
(0.198)\end{array}$ & $\begin{array}{c}1.064^{* * *} * \\
(0.196)\end{array}$ & $\begin{array}{c}1.075^{* * *} \\
(0.198)\end{array}$ & $\begin{array}{c}1.073^{* * * *} \\
(0.200)\end{array}$ & $\begin{array}{c}1.064^{* * *} * \\
(0.196)\end{array}$ \\
\hline Water & & $\begin{array}{c}-21.295^{* * *} \\
(0.296)\end{array}$ & $\begin{array}{c}-21.435^{* * * *} \\
(0.302)\end{array}$ & $\begin{array}{c}-21.293^{* * *} \\
(0.297)\end{array}$ & $\begin{array}{c}-21.283^{* * *} \\
(0.296)\end{array}$ & $\begin{array}{c}-21.282^{* * *} \\
(0.296)\end{array}$ & $\begin{array}{l}-18.699 \\
(692.79)\end{array}$ & $\begin{array}{c}-20.716^{* * *} \\
(0.296)\end{array}$ \\
\hline Transport & & $\begin{array}{r}-20.822 \\
(0.000)\end{array}$ & $\begin{array}{r}-20.890 \\
(0.000)\end{array}$ & $\begin{array}{l}-20.831 \\
(0.000)\end{array}$ & $\begin{array}{r}-20.828 \\
(0.000)\end{array}$ & $\begin{array}{r}-20.822 \\
(0.000)\end{array}$ & $\begin{array}{l}-18.930 \\
(692.79)\end{array}$ & $\begin{array}{c}-20.244 \\
(0.000)\end{array}$ \\
\hline
\end{tabular}

Significance levels: $* * * 0.01 ; * * 0.05 ; * 0.10$. Standard errors in parentheses. Reference category: in-house. 
Table 4. Multinomial logit regression estimations - Inter-municipal cooperation

\begin{tabular}{|c|c|c|c|c|c|c|c|c|}
\hline & (1) & $(2)$ & (3) & (4) & $(5)$ & $(6)$ & (7) & $(8)$ \\
\hline Population & $\begin{array}{c}0.000^{* * *} \\
(0.000)\end{array}$ & $\begin{array}{l}0.000^{*} \\
(0.000)\end{array}$ & $\begin{array}{c}0.000 \\
(0.000)\end{array}$ & $\begin{array}{c}0.000^{* *} \\
(0.000)\end{array}$ & $\begin{array}{l}0.000^{*} \\
(0.000)\end{array}$ & $\begin{array}{l}0.000^{*} \\
(0.000)\end{array}$ & $\begin{array}{c}0.000^{* * *} \\
(0.000)\end{array}$ & $\begin{array}{c}0.000^{* *} \\
(0.000)\end{array}$ \\
\hline Population sq. & & & & & & $\begin{array}{c}0.000 \\
(0.000)\end{array}$ & & \\
\hline Population*Water & & & & & & & $\begin{array}{c}0.000^{* * * *} \\
(0.000)\end{array}$ & \\
\hline Population*Transportation & & & & & & & $\begin{array}{l}0.000^{*} \\
(0.000)\end{array}$ & \\
\hline Labor Costs & $\begin{array}{c}0.000 \\
(0.000)\end{array}$ & $\begin{array}{l}-0.001 \\
(0.001)\end{array}$ & $\begin{array}{l}-0.001 \\
(0.001)\end{array}$ & $\begin{array}{l}-0.001 \\
(0.001)\end{array}$ & $\begin{array}{l}-0.001 \\
(0.001)\end{array}$ & $\begin{array}{l}-0.001 \\
(0.001)\end{array}$ & $\begin{array}{c}0.000 \\
(0.001)\end{array}$ & $\begin{array}{l}-0.001 \\
(0.001)\end{array}$ \\
\hline Labor Costs*Homecare & & & & & & & & $\begin{array}{l}-0.001 \\
(0.001)\end{array}$ \\
\hline Density & & & $\begin{array}{l}0.000^{*} \\
(0.000)\end{array}$ & & & & & \\
\hline Population Growth & $\begin{array}{c}0.031^{* *} \\
(0.015)\end{array}$ & $\begin{array}{l}-0.015 \\
(0.019)\end{array}$ & $\begin{array}{l}-0.005 \\
(0.020)\end{array}$ & $\begin{array}{l}-0.017 \\
(0.019)\end{array}$ & $\begin{array}{l}-0.016 \\
(0.019)\end{array}$ & $\begin{array}{l}-0.012 \\
(0.019)\end{array}$ & $\begin{array}{l}-0.017 \\
(0.020)\end{array}$ & $\begin{array}{l}-0.015 \\
(0.019)\end{array}$ \\
\hline Asset Specificity & $\begin{array}{c}-0.619^{* * *} \\
(0.101)\end{array}$ & $\begin{array}{c}-0.571^{* * *} \\
(0.107)\end{array}$ & $\begin{array}{c}-0.570^{* * *} \\
(0.107)\end{array}$ & $\begin{array}{c}0.806 \\
(0.669) \\
\end{array}$ & $\begin{array}{c}-0.579^{* * *} \\
(0.107)\end{array}$ & $\begin{array}{c}-0.572^{* * * *} \\
(0.107)\end{array}$ & $\begin{array}{c}-0.557^{* * *} \\
(0.108)\end{array}$ & $\begin{array}{c}-0.572^{* * *} \\
(0.107)\end{array}$ \\
\hline Asset Specificity sq. & & & & $\begin{array}{c}-0.203^{* *} \\
(0.099)\end{array}$ & & & & \\
\hline Ease of Monitoring & $\begin{array}{c}0.896^{* * *} \\
(0.068)\end{array}$ & $\begin{array}{c}0.853^{* * *} \\
(0.074)\end{array}$ & $\begin{array}{c}0.860^{* * *} \\
(0.074)\end{array}$ & $\begin{array}{c}0.844^{* * *} \\
(0.074)\end{array}$ & $\begin{array}{c}0.437 \\
(0.333) \\
\end{array}$ & $\begin{array}{c}0.854^{* * *} \\
(0.074)\end{array}$ & $\begin{array}{c}0.856^{* * *} \\
(0.074)\end{array}$ & $\begin{array}{c}.852^{* * *} \\
(0.074)\end{array}$ \\
\hline Ease of Monitoring sq. & & & & & $\begin{array}{c}0.068 \\
(0.059) \\
\end{array}$ & & & \\
\hline Income & & $\begin{array}{c}0.002^{* * * *} \\
(0.000)\end{array}$ & $\begin{array}{c}0.001^{* * *} \\
(0.000)\end{array}$ & $\begin{array}{c}0.002^{* * *} \\
(0.000)\end{array}$ & $\begin{array}{c}0.002^{* * *} \\
(0.000)\end{array}$ & $\begin{array}{c}0.002^{* * *} \\
(0.000)\end{array}$ & $\begin{array}{c}0.002^{* * *} \\
(0.000)\end{array}$ & $\begin{array}{c}0.002^{* * *} \\
(0.000)\end{array}$ \\
\hline Financial autonomy & & $\begin{array}{c}0.009 \\
(0.010)\end{array}$ & $\begin{array}{c}0.008 \\
(0.010)\end{array}$ & $\begin{array}{c}0.007 \\
(0.010)\end{array}$ & $\begin{array}{c}0.009 \\
(0.010)\end{array}$ & $\begin{array}{c}0.008 \\
(0.010)\end{array}$ & $\begin{array}{c}0.004 \\
(0.010)\end{array}$ & $\begin{array}{c}0.009 \\
(0.010)\end{array}$ \\
\hline Budget surplus & & $\begin{array}{c}0.000 \\
(0.000)\end{array}$ & $\begin{array}{c}0.000 \\
(0.000)\end{array}$ & $\begin{array}{c}0.000 \\
(0.000)\end{array}$ & $\begin{array}{c}0.000 \\
(0.000)\end{array}$ & $\begin{array}{c}0.000 \\
(0.000)\end{array}$ & $\begin{array}{c}0.000 \\
(0.000)\end{array}$ & $\begin{array}{c}0.000 \\
(0.000)\end{array}$ \\
\hline Debt & & $\begin{array}{c}0.000 \\
(0.000)\end{array}$ & $\begin{array}{c}0.000 \\
(0.000)\end{array}$ & $\begin{array}{c}0.000 \\
(0.000)\end{array}$ & $\begin{array}{c}0.000 \\
(0.000)\end{array}$ & $\begin{array}{c}0.000 \\
(0.000)\end{array}$ & $\begin{array}{c}0.000 \\
(0.000)\end{array}$ & $\begin{array}{c}0.000 \\
(0.000)\end{array}$ \\
\hline EU Expenditures & & $\begin{array}{c}0.000 \\
(0.000)\end{array}$ & $\begin{array}{c}0.000 \\
(0.000)\end{array}$ & $\begin{array}{c}0.000 \\
(0.000)\end{array}$ & $\begin{array}{c}0.000 \\
(0.000)\end{array}$ & $\begin{array}{c}0.000 \\
(0.000)\end{array}$ & $\begin{array}{c}0.000 \\
(0.000)\end{array}$ & $\begin{array}{c}0.000 \\
(0.000)\end{array}$ \\
\hline Political stability & & $\begin{array}{c}0.075 \\
(0.095)\end{array}$ & $\begin{array}{c}0.077 \\
(0.095)\end{array}$ & $\begin{array}{c}0.077 \\
(0.095)\end{array}$ & $\begin{array}{c}0.063 \\
(0.096)\end{array}$ & $\begin{array}{c}0.096 \\
(0.097)\end{array}$ & $\begin{array}{c}0.069 \\
(0.096)\end{array}$ & $\begin{array}{c}0.076 \\
(0.095)\end{array}$ \\
\hline Network embeddedness & & $\begin{array}{c}0.072^{* *} \\
(0.034)\end{array}$ & $\begin{array}{c}0.075^{* *} \\
(0.034)\end{array}$ & $\begin{array}{c}0.069^{* *} \\
(0.034)\end{array}$ & $\begin{array}{c}0.074^{* *} \\
(0.034)\end{array}$ & $\begin{array}{c}0.077^{* *} \\
(0.035)\end{array}$ & $\begin{array}{c}0.092^{* * *} \\
(0.035)\end{array}$ & $\begin{array}{c}0.072^{* *} \\
(0.034)\end{array}$ \\
\hline Location & & $\begin{array}{c}0.353^{* *} \\
(0.158)\end{array}$ & $\begin{array}{c}0.342^{* *} \\
(0.158)\end{array}$ & $\begin{array}{c}0.341^{* *} \\
(0.159)\end{array}$ & $\begin{array}{c}0.344^{* *} \\
(0.159)\end{array}$ & $\begin{array}{c}0.342^{* *} \\
(0.158)\end{array}$ & $\begin{array}{c}0.345^{* *} \\
(0.159)\end{array}$ & $\begin{array}{c}0.353^{* *} \\
(0.158)\end{array}$ \\
\hline Water & & $\begin{array}{c}-0.858^{* * *} \\
(0.170)\end{array}$ & $\begin{array}{c}-0.886^{* * *} \\
(0.171)\end{array}$ & $\begin{array}{c}-0.878^{* * *} \\
(0.170)\end{array}$ & $\begin{array}{c}-0.860^{* * *} \\
(0.170)\end{array}$ & $\begin{array}{c}-0.862^{* * *} \\
(0.170)\end{array}$ & $\begin{array}{l}-0.284 \\
(0.231)\end{array}$ & $\begin{array}{l}-0.652 \\
(0.547)\end{array}$ \\
\hline Transportation & & $\begin{array}{c}-2.463^{* * *} \\
(0.245)\end{array}$ & $\begin{array}{c}-2.478^{* * *} \\
(0.246)\end{array}$ & $\begin{array}{c}-2.488^{* * *} \\
(0.247)\end{array}$ & $\begin{array}{c}-2.449 * * * \\
(0.245)\end{array}$ & $\begin{array}{c}-2.460^{* * *} \\
(0.246)\end{array}$ & $\begin{array}{c}-2.621^{* * *} \\
(0.262)\end{array}$ & $\begin{array}{c}-2.260^{* * * *} \\
(0.565)\end{array}$ \\
\hline
\end{tabular}

Significance levels: $* * * 0.01 ; * * 0.05 ; * 0.10$. Standard errors in parentheses. Reference category: in-house. 
Table 5. Multinomial logit regression estimations - Private contracting

\begin{tabular}{|c|c|c|c|c|c|c|c|c|}
\hline & (1) & (2) & (3) & (4) & (5) & (6) & (7) & (8) \\
\hline Population & $\begin{array}{c}0.000^{* * *} \\
(0.000)\end{array}$ & $\begin{array}{l}0.000^{*} \\
(0.000)\end{array}$ & $\begin{array}{c}0.000 \\
(0.000)\end{array}$ & $\begin{array}{l}0.000^{*} \\
(0.000)\end{array}$ & $\begin{array}{l}0.000^{*} \\
(0.000)\end{array}$ & $\begin{array}{c}0.000 \\
(0.000)\end{array}$ & $\begin{array}{c}0.000 \\
(0.000)\end{array}$ & $\begin{array}{c}0.000 \\
(0.000)\end{array}$ \\
\hline Population sq. & & & & & & $\begin{array}{c}0.000 \\
(0.000)\end{array}$ & & \\
\hline Population*Water & & & & & & & $\begin{array}{c}0.000^{* * *} \\
(0.000)\end{array}$ & \\
\hline Population*Transportation & & & & & & & $\begin{array}{c}0.000 \\
(0.000)\end{array}$ & \\
\hline Labor Costs & $\begin{array}{c}0.000 \\
(0.001)\end{array}$ & $\begin{array}{c}-0.002^{* *} \\
(0.001)\end{array}$ & $\begin{array}{c}-0.001^{*} \\
(0.001)\end{array}$ & $\begin{array}{l}-0.002^{*} \\
(0.001)\end{array}$ & $\begin{array}{c}-0.002^{* *} \\
(0.001)\end{array}$ & $\begin{array}{c}-0.002^{*} \\
(0.001)\end{array}$ & $\begin{array}{l}-0.001 \\
(0.001)\end{array}$ & $\begin{array}{l}-0.002^{*} \\
(0.001)\end{array}$ \\
\hline Labor Costs*Homecare & & & & & & & & $\begin{array}{c}0.000 \\
(0.001)\end{array}$ \\
\hline Density & & & $\begin{array}{l}0.000^{*} \\
(0.000)\end{array}$ & & & & & \\
\hline Population Growth & $\begin{array}{c}0.014 \\
(0.016)\end{array}$ & $\begin{array}{l}-0.034 \\
(0.022)\end{array}$ & $\begin{array}{l}-0.024 \\
(0.023)\end{array}$ & $\begin{array}{l}-0.036^{*} \\
(0.022)\end{array}$ & $\begin{array}{c}-0.034 \\
(0.022)\end{array}$ & $\begin{array}{l}-0.033 \\
(0.022)\end{array}$ & $\begin{array}{c}-0.036 \\
(0.022)\end{array}$ & $\begin{array}{l}-0.034 \\
(0.022)\end{array}$ \\
\hline Asset Specificity & $\begin{array}{c}-0.758^{* * *} \\
(0.108)\end{array}$ & $\begin{array}{c}-0.628^{* * *} \\
(0.119)\end{array}$ & $\begin{array}{c}-0.626^{* * * *} \\
(0.119)\end{array}$ & $\begin{array}{c}0.857 \\
(0.754)\end{array}$ & $\begin{array}{c}-0.618^{* * * *} \\
(0.120)\end{array}$ & $\begin{array}{c}-0.625^{* * * *} \\
(0.119)\end{array}$ & $\begin{array}{c}-0.620^{* * * *} \\
(0.120)\end{array}$ & $\begin{array}{c}-0.628^{* * *} \\
(0.119)\end{array}$ \\
\hline Asset Specificity sq. & & & & $\begin{array}{c}-0.220^{*} \\
(0.113)\end{array}$ & & & & \\
\hline Ease of Monitoring & $\begin{array}{c}0.785^{* * *} \\
(0.073)\end{array}$ & $\begin{array}{c}0.692^{* * *} \\
(0.081)\end{array}$ & $\begin{array}{c}0.699^{* * *} \\
(0.081)\end{array}$ & $\begin{array}{c}0.683^{* * *} \\
(0.081)\end{array}$ & $\begin{array}{c}1.020^{* * *} \\
(0.382)\end{array}$ & $\begin{array}{c}0.692^{* * *} \\
(0.081)\end{array}$ & $\begin{array}{c}0.699^{* * *} \\
(0.081)\end{array}$ & $\begin{array}{c}0.692^{* * *} \\
(0.081)\end{array}$ \\
\hline Ease of Monitoring sq. & & & & & $\begin{array}{l}-0.055 \\
(0.067) \\
\end{array}$ & & & \\
\hline Income & & $\begin{array}{c}0.001^{* *} \\
(0.001)\end{array}$ & $\begin{array}{l}0.001^{*} \\
(0.001)\end{array}$ & $\begin{array}{c}0.001^{* *} \\
(0.001)\end{array}$ & $\begin{array}{c}0.001^{* *} \\
(0.001)\end{array}$ & $\begin{array}{c}0.001^{* *} \\
(0.001)\end{array}$ & $\begin{array}{c}0.001^{* *} \\
(0.001)\end{array}$ & $\begin{array}{c}0.001^{* *} \\
(0.001)\end{array}$ \\
\hline Financial autonomy & & $\begin{array}{l}0.000 \\
(0.012)\end{array}$ & $\begin{array}{l}-0.001 \\
(0.012)\end{array}$ & $\begin{array}{l}-0.003 \\
(0.012)\end{array}$ & $\begin{array}{l}0.000 \\
(0.012)\end{array}$ & $\begin{array}{l}-0.001 \\
(0.012)\end{array}$ & $\begin{array}{l}-0.004 \\
(0.012)\end{array}$ & $\begin{array}{l}0.000 \\
(0.012)\end{array}$ \\
\hline Budget surplus & & $\begin{array}{c}0.000 \\
(0.000)\end{array}$ & $\begin{array}{c}0.000 \\
(0.000)\end{array}$ & $\begin{array}{c}0.000 \\
(0.000)\end{array}$ & $\begin{array}{c}0.000 \\
(0.000)\end{array}$ & $\begin{array}{c}0.000 \\
(0.000)\end{array}$ & $\begin{array}{c}0.000 \\
(0.000)\end{array}$ & $\begin{array}{c}0.000 \\
(0.000)\end{array}$ \\
\hline Debt & & $\begin{array}{c}0.000 \\
(0.000)\end{array}$ & $\begin{array}{c}0.000 \\
(0.000)\end{array}$ & $\begin{array}{l}0.000^{*} \\
(0.000)\end{array}$ & $\begin{array}{c}0.000 \\
(0.000)\end{array}$ & $\begin{array}{c}0.000 \\
(0.000)\end{array}$ & $\begin{array}{c}0.000 \\
(0.000)\end{array}$ & $\begin{array}{c}0.000 \\
(0.000)\end{array}$ \\
\hline EU Expenditures & & $\begin{array}{c}0.000 \\
(0.000)\end{array}$ & $\begin{array}{c}0.000 \\
(0.000)\end{array}$ & $\begin{array}{c}0.000 \\
(0.000)\end{array}$ & $\begin{array}{c}0.000 \\
(0.000)\end{array}$ & $\begin{array}{c}0.000 \\
(0.000)\end{array}$ & $\begin{array}{c}0.000 \\
(0.000)\end{array}$ & $\begin{array}{l}0.000 \\
(0.000)\end{array}$ \\
\hline Political stability & & $\begin{array}{l}0.183^{*} \\
(0.108)\end{array}$ & $\begin{array}{l}0.185^{*} \\
(0.108)\end{array}$ & $\begin{array}{l}0.185^{*} \\
(0.108)\end{array}$ & $\begin{array}{l}0.193^{*} \\
(0.109)\end{array}$ & $\begin{array}{l}0.191^{*} \\
(0.110)\end{array}$ & $\begin{array}{c}0.177 \\
(0.109)\end{array}$ & $\begin{array}{l}0.182^{*} \\
(0.108)\end{array}$ \\
\hline Network embeddedness & & $\begin{array}{c}0.087^{* *} \\
(0.039)\end{array}$ & $\begin{array}{c}0.089^{* *} \\
(0.039) \\
\end{array}$ & $\begin{array}{c}0.083^{* *} \\
(0.039) \\
\end{array}$ & $\begin{array}{c}0.087^{* *} \\
(0.039)\end{array}$ & $\begin{array}{l}0.089^{* *} \\
(0.039) \\
\end{array}$ & $\begin{array}{c}0.105^{* * *} \\
(0.039)\end{array}$ & $\begin{array}{c}0.087^{* *} \\
(0.039) \\
\end{array}$ \\
\hline Location & & $\begin{array}{c}0.655^{* * *} \\
(0.178)\end{array}$ & $\begin{array}{c}0.645^{* * *} \\
(0.178)\end{array}$ & $\begin{array}{c}0.641^{* * * *} \\
(0.178)\end{array}$ & $\begin{array}{c}0.656^{* * *} \\
(0.178)\end{array}$ & $\begin{array}{c}0.655^{* * * *} \\
(0.178)\end{array}$ & $\begin{array}{c}0.650^{* * * *} \\
(0.178)\end{array}$ & $\begin{array}{c}0.655^{* * *} \\
(0.177)\end{array}$ \\
\hline Water & & $\begin{array}{c}-0.536^{* * * *} \\
(0.202)\end{array}$ & $\begin{array}{c}-0.560 * * * \\
(0.203)\end{array}$ & $\begin{array}{c}-0.560^{* * * *} \\
(0.202)\end{array}$ & $\begin{array}{c}-0.534^{* * * *} \\
(0.202)\end{array}$ & $\begin{array}{c}-0.537^{* * *} \\
(0.202)\end{array}$ & $\begin{array}{c}0.112 \\
(0.253)\end{array}$ & $\begin{array}{l}-0.649 \\
(0.608)\end{array}$ \\
\hline Transportation & & $\begin{array}{c}-3.299^{* * * *} \\
(0.248)\end{array}$ & $\begin{array}{c}-3.313^{* * *} \\
(0.249)\end{array}$ & $\begin{array}{c}-3.327^{* * * *} \\
(0.250)\end{array}$ & $\begin{array}{c}-3.315^{* * * *} \\
(0.249)\end{array}$ & $\begin{array}{c}-3.295^{* * *} \\
(0.248)\end{array}$ & $\begin{array}{c}-3.375^{* * *} \\
(0.265)\end{array}$ & $\begin{array}{c}-3.411^{* * * *} \\
(0.615)\end{array}$ \\
\hline
\end{tabular}

Significance levels: $* * * 0.01 ; * * 0.05 ; * 0.10$. Standard errors in parentheses. Reference category: in-house. 
Table 6. Multinomial logit regression models - number of observations, significance and quality of the models

\begin{tabular}{|l|c|c|c|c|c|c|c|c|}
\hline & $\mathbf{( 1 )}$ & $\mathbf{( 2 )}$ & $\mathbf{( 3 )}$ & $\mathbf{( 4 )}$ & $\mathbf{( 5 )}$ & $\mathbf{( 6 )}$ & $\mathbf{( 7 )}$ & $\mathbf{( 8 )}$ \\
\hline $\mathbf{N}$ & 1809 & 1809 & 1809 & 1809 & 1809 & 1809 & 1809 & 1809 \\
\hline Wald chi2 & 504.06 & 1366.16 & 1376.48 & 1377.50 & 1371.76 & 1367.69 & 1393.36 & 1366.43 \\
\hline Prob>chi2 & 0.000 & 0.000 & 0.000 & 0.000 & 0.000 & 0.000 & 0.000 & 0.000 \\
\hline Pseudo R2 (Nagelkerke) & 0.264 & 0.576 & 0.579 & 0.579 & 0.578 & 0.576 & 0.584 & 0.576 \\
\hline
\end{tabular}




\section{References}

Bel, G. and Fageda, X. (2010) 'Partial privatisation in local services delivery: An empirical analysis of the choice of mixed firms', Local Government Studies, 36(1), pp. 129-149.

Bel, G. and Fageda, X. (2017) 'What have we learned from the last three decades of empirical studies on factors driving local privatisation?', Local Government Studies, 43(4), pp. 503-511.

Bel, G., Fageda, X. and Mur, M. (2013) 'Why Do Municipalities Cooperate to Provide Local Public Services? An Empirical Analysis', Local Government Studies, 39(3), pp. 435-454.

Bel, G., Fageda, X. and Mur, M. (2014) 'Does Cooperation Reduce Service Delivery Costs? Evidence from Residential Solid Waste Services', Journal of Public Administration Research and Theory, 24(1), pp. 85-107.

Bel, G. and Sebő, M. (2019) 'Does Inter-Municipal Cooperation Really Reduce Delivery Costs? An Empirical Evaluation of the Role of Scale Economies, Transaction Costs, and Governance Arrangements', Urban Affairs Review. doi: 10.1177/1078087419839492.

Bel, G. and Warner, M. E. (2016) 'Factors explaining inter-municipal cooperation in service delivery: a meta-regression analysis', Journal of Economic Policy Reform, 19(2), pp. 91-115.

Borooah, V. K. (2002) Logit and probit: Ordered and multinomial models. Sage.

Bourdeaux, C. (2005) 'A question of genesis: An analysis of the determinants of public authorities', Journal of Public Administration Research and Theory, 15(3), pp. 441-462.

Brown, T. L. and Potoski, M. (2003a) 'Managing contract performance: A transaction costs approach', Journal of Policy Analysis and Management. 22(2), pp. 275-297.

Brown, T. L. and Potoski, M. (2003b) 'Transaction Costs and Institutional Explanations for Government Service Production Decisions', Journal of Public Administration Research and Theory, 13(4), pp. 441-468.

Carr, J. B., LeRoux, K. and Shrestha, M. (2009) 'Institutional ties, transaction costs, and external service production', Urban Affairs Review, 44(3), pp. 403-427.

Clingermayer, J. C. and Feiock, R. C. (1997) 'Leadership Turnover, Transacton Costs, and External City Service Delivery’, Public Administration Review, 57(3), pp. 231-239.

Feiock, R. C., Clingermayer, J. C. and Dasse, C. (2003) 'Sector choices for public service delivery transaction costs implications of executive turnover', Public Management Review, 5(2), pp. 163-176.

Ferris, J. and Graddy, E. (1986) 'Contracting out: For What? With Whom?', Public Administration Review. 46(4), p. 332.

Ferris, J. M. and Graddy, E. (1991) 'Production Costs, Transaction Costs, and Local Government Contractor Choice', Economic Inquiry, 29(3), pp. 541-554.

Ferris, J. M. and Graddy, E. (1994) 'Organizational choices for public service supply', Journal of Law, Economics, \& Organization, 10(1), pp. 126-141.

Hefetz, A., and Warner, M. E. (2012) 'Contracting or Public Delivery? The Importance of Service, Market, and Management Characteristics', Journal of Public Administration Research and Theory, 22(2), 289-317.

Hefetz, A., Warner, M. E., and Vigoda-Gadot, E. (2012), 'Privatization and Intermunicipal 
Contracting: the US Local Government Experience 1992-2007', Environment and Planning C: Government and Policy, 30(4), 675-692.

Kołsut, B. (2015) Zinstytucjonalizowane sieci współdziałania międzygminnego w Polsce. Poznan: Wydawnictwo Bogucki.

Ladd, H. F. (1992) 'Population Growth, Density and the Costs of Providing Public Services', Urban Studies, 29(2), pp. 273-95.

Ladner, A. et al. (eds.) (2019) Patterns of Local Autonomy in Europe. Basingstoke: Palgrave Macmillan.

LeRoux, K. and Carr, J. B. (2007) 'Explaining Local Government Cooperation on Public Works: Evidence From Michigan', Public Works Management \& Policy, 12(1), pp. 344-358.

Levin, J. and Tadelis, S. (2010) 'Contracting for government services: Theory and evidence from U.S. cities', Journal of Industrial Economics. National Bureau of Economic Research, Inc, 58(3), pp. 507-541.

Liao, T. F. (1994) 'Interpreting probability models: Logit, probit, and other generalized linear models'. Sage.

Łukomska, J. and Szmigiel-Rawska, K. (2019) 'Inter-local relations and trans-scaling through finance in Poland', Journal of Economic Policy Reform, 22(2), pp. 184-201.

Morgan, D. R., Hirlinger, M. W. and England, R. E. (1988) 'The Decision To Contract Out City Services: a Further Explanation’, Political Research Quarterly, 41(2), pp. 363-372.

Nelson, M. A. (1997) 'Municipal government approaches to service delivery: An analysis from a transactions cost perspective’, Economic Inquiry, 35(1), pp. 82-96.

Pallesen, T. (2004) 'A political perspective on contracting out: The politics of good times. Experiences from Danish local governments', Governance, 17(4), pp. 573-587.

Petersen, O. H., Hjelmar, U. and Vrangbæk, K. (2018) 'Is Contracting out of Public Services still the Great Panacea? A Systematic Review of Studies on Economic and Quality Effects from 2000 to 2014', Social Policy and Administration, 52(1), pp. 130-157.

Rodrigues, M. and Tavares, A. F. (2017) 'The same deep water as you? The impact of alternative governance arrangements of water service delivery on efficiency', Journal of Strategic Contracting and Negotiation 3(2), pp. 78-101.

Rodrigues, M., Tavares, A. F. and Araújo, J. F. (2012) 'Municipal Service Delivery: The Role of Transaction Costs in the Choice between Alternative Governance Mechanisms', Local Government Studies. 38(5), pp. 615-638.

Shrestha, M. K. and Feiock, R. C. (2011) 'Transaction Cost, Exchange Embeddedness, and Interlocal Cooperation in Local Public Goods Supply', Political Research Quarterly, 64(3), pp. 573-587.

Tavares, A. F. and Camões, P. J. (2007) 'Local service delivery choices in Portugal: A political transaction costs framework', Local Government Studies, 33(4), pp. 535-553.

Tavares, António F. and Camões, P. J. (2010) 'New forms of local governance: A theoretical and empirical analysis of municipal corporations in Portugal', Public Management Review, 12(5), pp. 587-608.

Teles, F. (2016), Local Governance and Inter-Municipal Cooperation. Basingstoke: Palgrave. 
Teles, F. and Swianiewicz, P. (eds.) (2018), Inter-Municipal Cooperation in Europe: Institutions and Governance. Basingstoke: Palgrave.

Voorn, B., van Genugten, M. and van Thiel, S. (2019) 'Multiple principals, multiple problems: Implications for effective governance and a research agenda for joint service delivery', Public Administration. Wiley-Blackwell. doi: 10.1111/padm.12587.

Wassenaar, M., Groot, T. and Gradus, R. (2013) 'Municipalities' Contracting Out Decisions: An Empirical Study on Motives', Local Government Studies. 39(3), pp. 414-434.

Williamson, O. E. (1979) 'Transaction-Cost Economics: The Governance of Contractual Relations', The Journal of Law and Economics, 22(2), pp. 233-261.

Zafra-Gómez, J. L. et al. (2016) 'Financial and Political Factors Motivating the Privatisation of Municipal Water Services’, Local Government Studies. 42(2), pp. 287-308.

Zullo, R. (2009) 'Does fiscal stress induce privatization? Correlates of private and intermunicipal contracting, 1992-2002', Governance, 22(3), pp. 459-481. 